THE ANATOMY OF A SCIENTIFIC INSTITUTION:

THE PARIS ACADEMY OF SCIENCES, I 666-1803 



\section{The Anatomy of a Scientific Institution}

\section{The Paris Academy of Sciences, 1666-1803 \\ by Roger Hahn}

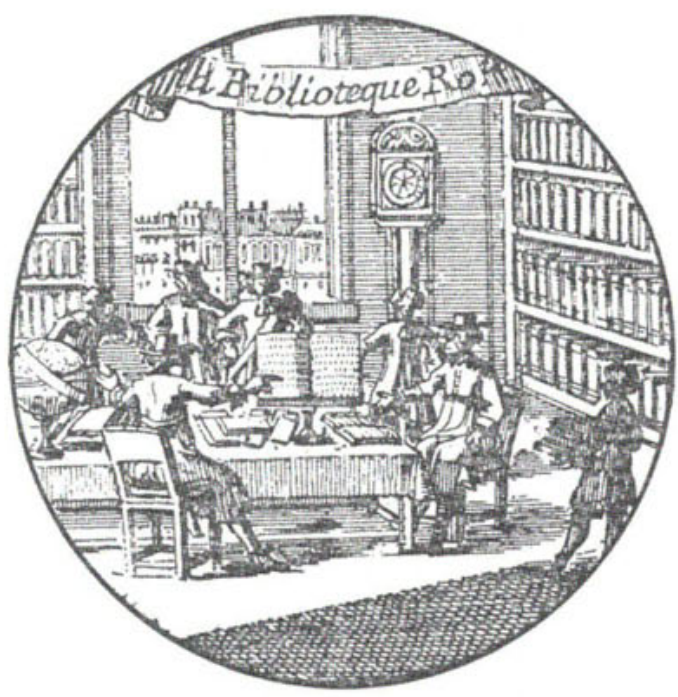

UNIVERSITY OF CALIFORNIA PRESS

BERKELEY, LOS ANGELES, LONDON I 97 I 
UNIVERSITY OF CALIFORNIA PRESS BERKELEY AND LOS ANGELES, CALIFORNIA UNIVERSITY OF CALIFORNIA PRESS, LTD. LONDON, ENGLAND COPYRIGHT (C) I97I, BY THE REGENTS OF THE UNIVERSITY OF CALIFORNIA TRANSLATION RIGHTS RESERVED FOR ROGER HAHN ISBN: 0-520-O I $818-4$ LIBRARY OF CONGRESS CATALOG CARD NUMBER: 70-I 30795 PRINTED IN THE UNITED STATES OF AMERICA DESIGNED BY DAVE COMSTOCK 
To Henry Guerlac
Scholar, teacber, and friend 
